\section{New Brunswick}

\section{Unusual Support for Student}

Boyd Pittman, a master's student of Corner Brook, Newfoundland, working under the supervision of Professor G.A. Jordan, Forest Resources, has received an unusually high level of funding. First, Boyd received the Fraser Inc. Scholarship for $\$ 1500$. Second, Corner Brook Pulp and Paper Co. and the Newfoundland Department of Forestry and Agriculture have provided, through a contractual arrangement, almost $\$ 50,000$ (includes UNB overhead) to fund Boyd's research over the next two years.

\section{Faculty Briefs...}

Dr. R.A. Douglas, Forest Engineering, presented a paper at the annual winter meeting of the American Society of Agricultural Engineers in Chicago in December. It was entitled "The Canadian National Forest Trucks and Roads Survey.",

At the same meeting, he was named chairman of Committee FE-12, Roads and Transportation, in the Forest Engineering Group.

Dr. M.S. Jamnick, Forest Resources, conducted a two-day workshop (in cooperation with the private consulting firm "Resource/Environmental Management Systems"') under the title "An Introduction to the Woodstock Forest Management Simulation System."' This was held on the UNB Fredericton campus in December. Marketing board and NB Department of Natural Resources and Energy personnel attended.

He was also scheduled to present a paper jointly with Professor E.W. Robak, Forest Engineering, at the 53.04.01 IUFRO meeting in Christchurch, New Zealand, at the end of January. The paper was entitled "An Integrated Forestry Planning System", and the meeting addressed the general topic of "Integrated Decision-Making in Planning and Control of Forest Operations.',

Professor E.J. Rickards, chairman of Forest Engineering, presented a paper and chaired a workshop at Oregon State University in December. The conference theme was "Mechanized Harvesting," his invited paper was entitled "Mechanization Depends on the Management of Maintenance,' ' and the workshop he chaired carried the title of "Logging Safety and Ergonomics.'

Dr. M.R. Roberts, Forest Resources, presented a paper at the Northeast Weed Science Society meeting, held in Boston, Massachusetts, January 6-9. The paper, entitled "Potential Levels of Raspberry Competition after Forest Floor Disturbance," was co-authored by former graduate student H. Dong.
Dr. M.H. Schneider, Forest Resources, was one of the instructors for a lumber dry kiln course, held at the Maritime Forest Ranger School, November 18-22.

He was also involved in the production of the following journal articles:

Schneider, M.H., Sebastian, L.P. and Seepersad, J. 1991. Bending Strength and Stiffness of Caribbean Pine from Trinidad and Tobago. Wood and Fibre Science 23(4): 468-471.

Schneider, M.H. and Phillips, J.G. 1991. Elasticity of Wood and Wood Polymer Composites in Tension, Compression and Bending. Wood Science and Technology 25: 361-364.

Schneider, M.H., Brebner, K.I. and Hartley, I. 1991. Swelling of a Cell Lumen Filled and a Cell-Wall Bulked Wood Polymer Composite in Water. Wood and Fibre Science 23(2): 165-172.

\section{Alex Dickson}

\section{Toronto \\ Student Receives CWPA Award}

Graduate student Dave Alexander received the Canadian Wood Preservation Association's student award for 1991 for his Masters' research on CCA fixation in wood. He presented a paper along with Professor Paul Cooper at the CWPA's 12th annual meeting last November in Vancouver. Alexander received \$500 and membership in the association.

Professor Cooper also presented a paper on "diffusion and microdistribution of wood treating chemicals in the wood cell wall,', and another entitled "Studies on railway tie deterioration"' with Dr. Tony Ung, also of the Faculty of Forestry.

\section{Professor Speaks to Constitutional Committee}

Dr. Paul Aird made a presentation on behalf of Canada's plants and animals, to the joint Senate and House of Commons constitutional committee that toured the country last fall. A professor of forest policy, he also made a similar presentation to a constitutional committee in 1981. At that time, the suggestion that Canada should honour and respect its natural heritage in its constitution was rejected. However, the government of Canada now proposes to add a Canada clause that covers conservation and sustainable development. Dr. Aird suggested a draft for the clause, stating that all levels of government strive to sustain the diversity of Canada's natural environment. He added that "the highest priority must be devoted to the conservation of soil, water, air, plants, animals, micro-organisms and habitats to sustain their use, benefit, enjoyment and appreciation by everyone.

\section{Biomass Research to Continue}

The International Energy Agency has renewed its Bioenergy Agreement for another three years, from 1992 to 1994. Professor Louis Zuffa and Dr. Robert Gambles of $\mathrm{U}$ of $\mathrm{T}$ coordinate one division of the research, designing and developing efficient and environmentally-sound biomass systems. The researchers are looking at short rotation systems, conventional forestry systems, and other biomass crop production systems. Environmental studies include the use of waste waters and sludges as fertilizers in biomass plantations, cleaning agricultural fertilizers and other chemical runoff from surface and ground water by growing biomass for energy, and the effect of production systems on forest wildlife conservation.

\section{Collaborative Research with China}

Associate Dean Terry Blake has undertaken a five-year collaborative research project with the Chinese Academy of Forestry. Professor Blake is working as a consultant for the Food and Agriculture Organization of the United Nations. He is developing physiological procedures for early selection of poplar clones, based on their drought tolerance. He has travelled twice to China, to start physiological testing and to evaluate afforestation trails on old coal mining wasteland areas in Huaibei province. Huaibei is in the warm, temperate regions of central and southeast China. Next summer Dr. Blake will travel to Liaoning Province in China's far north, to develop tests to select clone trees for the cooler, more arid regions of Inner Mongolia.

\section{Haliburton Forest and Wildlife Reserve}

Dr. Peter Schleifenbaum believes that one forested area can be managed to serve a wide variety of purposes. A German forester, Dr. Schleifenbaum came to Canada in 1988 and owns and manages a 20,000 acre forest, of which 10,000 acres are lakes. He made a presentation on his system of integrated management to Faculty members on December 4.

While the forest is not profitable in the Ontario sense, it makes a secure one to two percent each year. He manages it as a very long term investment, with a European point-of-view. The reserve has 340 semiwilderness campsites, 18 hunting lodges in hunting zones, nature trails, a sugar shack, fishing lakes, and $300 \mathrm{~km}$ of snowmobile trails. The forest is selection logged, using horse crews whenever possible. Twenty per- 


\section{Consider the Competition Covered Brush Blanket ${ }^{\circledR}$ special green mulch film - prevents weed growth, increases soil temperature and root development and promotes earlier crop maturity. \\ Herbicides, weeds, grass and brush clearing in the first three years of a new forest can now be eliminated - in the most environmentally friendly way. The IRT-76 film blocks most of the solar spectrum which supports photosynthesis and weed growth. Micro-perforation allows the soil to breath and water to penetrate. Improves seedling caliper and needle count.

cent of Dr. Schleifenbaum's gross revenue comes from logging, and the rest from charges for the various facilities that he has.

The World Wildlife Fund, Canadian Wildlife Service, Ontario Humane Society, and other groups are involved in various projects at the Haliburton Forest. PhD student Gary Bull is now working with Dr. Schleifenbaum to conduct $\mathrm{U}$ of $\mathrm{T}$ research there as well.

\section{High School Essay Contest}

To interest high school students in exploring forestry issues, the Faculty of Forestry at the University of Toronto is holding its second annual high school essay contest. Last year, over 2,500 students participated. This year's contest, called Forests of the Future, has five suggested essay topics: Managing urban forests; Chemical and biological pest control; Protecting wildlife habitat; Clear cutting versus selection cutting; and Resolving conflicts over forest use.

Backpacks and sweatshirts will be awarded to the two students in each participating class whose essays were judged the winners by their teachers. After reviewing all the winning essays, the Faculty will choose five first prize winners and ten second prize winners, who will be awarded $\$ 100$ and $\$ 50$ prizes.

High school teachers who would like to participate can contact Fleur Macqueen at the Faculty of Forestry, University of Toronto, Earth Sciences Centre, 33 Willcocks Street, Toronto, Ontario M5S 3B3, phone (416) 978-5749, fax (416) 978-3834.

\section{High School Visits}

Faculty members and undergraduate students have visited a number of high school classes and career days recently as part of the Faculty's ongoing program to inform high school students about forestry issues, and possibly interest them in studying forestry. One science class, from West End Alternative High School in Toronto, came to the Earth Sciences Centre for a day in
December. They talked about basic tree identification methods with Professor Jane Young, and then went into the Faculty's courtyard to identify trees. They also toured the forest entomology, genetics, and soils labs. They finished the afternoon at the urban entomology lab, finding out about research into sand barriers Dr. Myles and his research associates are investigating how to control termites.

Any alumni who are interested in visiting high schools in their area can contact Fleur Macqueen, (416) 979-5749, or at the Faculty address.

\section{Recent Appointments}

Dr. Jagdish Nautiyal is serving as Acting Dean of the Faculty of Forestry during Dean J. Rod Carrow's administrative leave. Dean Carrow will return on July 1, 1992.

Dr. Paul Webb, Research Manager of the Ministry of Natural Resources' Ontario Forest Research Institute, has been appointed an Adjunct Professor of EcoPhysiology. Dr. Webb is serving on graduate student committees and participating in cooperative research.

\section{Fleur Macqueen}

\section{British Columbia}

\section{Faculty News}

The ninth Leslie L. Schaffer Lecture in Forest Science was given this year on December 3 by Dr. Peter Morand, President of the Natural Sciences and Engineering Research Council of Canada. His talk was entitled "Challenges in Forestry Research". The Leslie L. Schaffer Lectureship in Forest Sciences was established in the memory of Leslie L. Schaffer, D. Sc., former vicepresident of Western Plywood Co. Ltd., by Mrs. Leslie L. Schaffer to finance lectures and publications by visiting forest scientists at the Faculty of Forestry, U.B.C. Copies of Dr. Morand's talk will be available in mid February by writing to: Forestry Publications, Faculty of Forestry, University of British Columbia, 2357 Main Mall, Van- couver, B.C. V6T 1Z4. Dr. Morand's talk was followed by a highly successful Faculty Research Day with more than twenty poster displays and tree talks covering forestry-related research from across campus.

Dean Clark S. Binkley is pleased to announce the recent hiring of Donna Goss B.S.F., as the Coordinator of Student Services (admissions, job placement, and public relations).

\section{Forest Sciences}

Professor Thomas G. Northcote retired on December 31, 1991, after over thirty years as a most valued member of the Faculty of Forestry. Tom was responsible for a fishforestry course which explored the interaction of management activities of these two natural resources, primarily on the British Columbia coast. His innovative research program was largely concerned with factors affecting populations of fish, again in lakes and streams on the British Columbia coast. His long career took him to many parts of the world including Europe and Peru where he coordinated an in-depth study of factors affecting the pollution of Lake Titicaca, and the Antipodes. His pleasant nature, vigorous activity and excellent science will be greatly missed by all.

\section{Forest Harvesting and Wood Science}

As December 31, 1991, Dr. Robert Kennedy has taken early retirement from his position of Professor in the Department of Harvesting and Wood Science. Dr. Kennedy served as Dean, U.B.C. Forestry, from 1983 to 1990 , during a period of rapid growth in both academic staff and research funding. He has been active in a wide range of national and international professional and forest-industry organizations, while also being elected as a Fellow of the International Academy of Wood Sciences. His career has combined both university and industrial related research management in forest products.

Susan B. Watts, Ph.D., R.P.F. 